\title{
The impact of dietary sugarcane addition to finishing diets on performance, apparent digestibility, and fatty acid composition of Holstein $\times$ Zebu bulls ${ }^{1}$
}

\author{
P. P. Rotta, ${ }^{*}{ }^{2}$ S. C. Valadares Filho, ${ }^{*}$ T. E. Engle, $\dagger$ L. F. Costa e Silva, ${ }^{*} \dagger$ \\ D. F. T. Sathler,* I. N. Prado, E. G. Bonafé,§ F. Zawadzki, $\$$ and J. V. Visentainer§ \\ *Universidade Federal de Viçosa, Animal Science Department, 36571-000, Viçosa, Minas Gerais, Brazil; \\ $\dagger$ Colorado State University, Animal Science Department, 80523, Fort Collins; \\ ¥Universidade Estadual de Maringá, Animal Science Department, 87020-900, Maringá, Paraná, Brazil; \\ and §Universidade Estadual de Maringá, Chemistry Department, 87020-900, Maringá, Paraná, Brazil
}

\begin{abstract}
The objective of this study was to evaluate the influence of corn silage (CS) or sugarcane (SC) additions to finishing diets on voluntary intake, apparent digestibility, animal performance, and LM fatty acid (FA) composition in crossbred Holstein $\times$ Zebu bulls. Forty-two bulls (initial BW $328 \pm 39.2 \mathrm{~kg}$ and an initial age of $23.5 \mathrm{mo}$ ) were used in this experiment. A completely randomized design was used to examine roughage source (CS vs. SC) and ratio of concentrate (CO) on nutrient utilization and production. The experimental diets consisted of 1) $60 \% \mathrm{CS}$ and $40 \% \mathrm{CO}$ on DM basis fed for $84 \mathrm{~d}$ (CS60:40), 2) 60\% CS and 40\% CO on DM basis fed for $42 \mathrm{~d}$ and $40 \% \mathrm{CS}$ and $60 \% \mathrm{CO}$ on DM basis fed for $42 \mathrm{~d}$ (CS reverse diet [CSR]), 3) 40\% CS and 60\% $\mathrm{CO}$ on DM basis fed for $84 \mathrm{~d}$ (CS40:60), 4) $60 \% \mathrm{SC}$ and $40 \%$ CO on DM basis fed for $84 \mathrm{~d}$ (SC60:40), 5) 60\% SC and $40 \%$ CO on DM basis fed for $42 \mathrm{~d}$ and $40 \%$ SC
\end{abstract}

and $60 \% \mathrm{CO}$ on DM basis fed for $42 \mathrm{~d}$ (SC reverse diet [SCR]), and 6) $40 \% \mathrm{SC}$ and $60 \% \mathrm{CO}$ on DM basis fed for $84 \mathrm{~d}$ (SC40:60). Dry matter and NDF intakes were greater $(P<0.01)$ in bulls fed CS-based diets than bulls fed SC-based diets. The greatest $(P<0.01) \mathrm{DM}$ and CP digestibility were observed in bulls fed SC-based diets. Bulls fed CSR and CS40:60 had greater $(P<0.01)$ ADG than bulls fed SC-based diets. However, ADG was similar $(P=0.52)$ in bulls fed CS60:40, CSR, and SC40:60 diets. The percentage of $\mathrm{C} 18: 3 n-3$ and $\mathrm{C} 20: 5 n-3$ were greater $(P<0.01)$ in LM of bulls fed SC-based diets. The percentage of CLA was greater $(P<0.01)$ in LM of bulls fed SC60:40 than those fed CS-based diets. The findings of the present study indicate that SC40:60 can replace CS60:40 and CSR in finishing diets and, moreover, roughage source significantly altered the FA composition of crossbred Holstein $\times$ Zebu bulls LM.

Key words: beef, bulls, carcass characteristics, conjugated linoleic acid, feed intake, urea

(C) 2014 American Society of Animal Science. All rights reserved.

J. Anim. Sci. 2014.92:2641-2653 doi:10.2527/jas2013-7251

\section{INTRODUCTION}

Corn silage (CS) is considered the standard roughage source for feedlots in Brazil because of its high production per unit area and for its ability to be stored for extended periods of time while maintaining good nutritional value and palatability (Segers et al., 2013). However, the production of ethanol has increased the world demand for corn and has driven up the price of CS.

\footnotetext{
${ }^{1}$ This study was made possible by grants from CNPq-INCT/Ciência Animal and FAPEMIG.

${ }^{2}$ Corresponding author: polyana.rotta@ufv.br

Received October 11, 2013.

Accepted March 20, 2014.
}

Sugarcane (SC) is a roughage feed that can potentially replace CS. Sugarcane has DM yield (average of $90 \mathrm{t} / \mathrm{ha}$ in Florida), increases in digestibility with increasing maturity (Creek and Squire, 1976), and retains its nutritive value for many months after maturity (Pate et al., 1985). Because the DMI is lower in cattle consuming SC-compared to CS-based diets, it is necessary to increase the dietary concentrate $(\mathbf{C O})$ inclusion rate to obtain similar performance as that obtained in bulls fed CS-based diets (Fernandes et al., 2007).

In some countries, particularly those in Europe, the beef consumer market has declined due to negative factors associated with meat quality (Van Wezemael et al., 2012). Nevertheless, beef contains long-chain omega 3 PUFA (n-3) that are important to human health (Smith, 
Table 1. Ingredients and analyzed chemical compositions of feed used in experimental diets

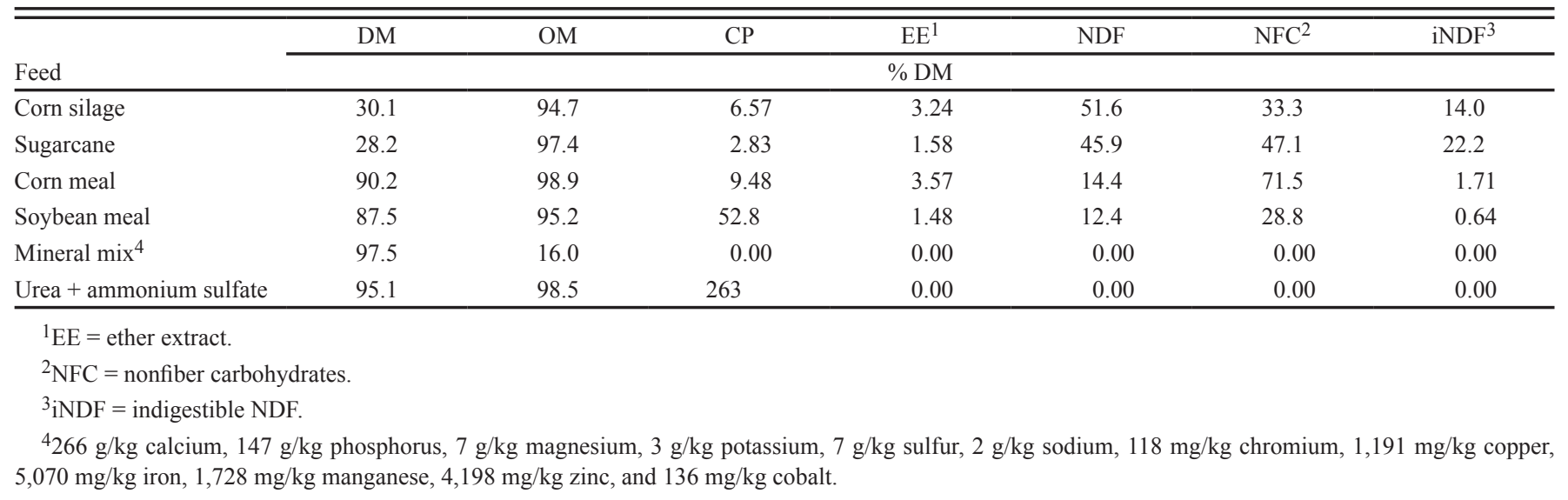

2008). Additionally, the CLA positional isomer C18:2 cis-9, trans-11 is present in greater concentrations in beef than in other meats (Rotta et al., 2009).

Fernandes et al. (2009) reported that the addition of SC in beef cattle diets increased $n-3$ fatty acids (FA; \% of total FA) compared to cattle receiving CS-based diets; the diets evaluated by Fernandes et al. (2009) contained $40 \%$ CO in both SC- and CS-based diets. Therefore, SC addition in feedlot cattle diets represents an approach for altering the FA composition of LM in beef cattle (Fernandes et al., 2007).

Therefore, the objective of this study was to evaluate the influence of CS or SC addition to finishing diets on voluntary intake, apparent digestibility, animal performance, and LM FA composition in crossbred Holstein $\times$ Zebu bulls.

\section{MATERIALS AND METHODS}

This study was approved by the Institutional Animal Care and Use Committee (IACUC) at the Universidade Federal de Viçosa (IACUC number 77/2013).

\section{Bulls, Feeds, Experimental Design, and Feed Sampling}

Forty-two crossbred Holstein $\times$ Zebu (five-eighths Holstein $\times$ three-eighths Nellore) bulls (initial BW $328 \pm$ $39.2 \mathrm{~kg}$ and an initial age of $23.5 \mathrm{mo}$ ) were used in a completely randomized design. The total length of the experiment was of $114 \mathrm{~d}$, which consisted of $30 \mathrm{~d}$ of acclimation and $84 \mathrm{~d}$ divided into 4 periods of $21 \mathrm{~d}$ each. Bulls were housed in $30 \mathrm{~m}^{2}$ individual pens $\left(8 \mathrm{~m}^{2}\right.$ were covered) with full concrete floors, individual bunks, and automatic water.

Before the initiation of the experiment, bulls were acclimated to the experimental pens for $30 \mathrm{~d}$ during which they received an ad libitum diet composed of grass silage and CO (70:30 on DM basis). After the 30-d acclimation period, all bulls were weighed (after a 16-h feed withdrawal period). Animals had free access to water during the withdrawal period. Pens were then randomly assigned to treatments. Treatments consisted of 1) $60 \% \mathrm{CS}$ and $40 \% \mathrm{CO}$ on DM basis fed for $84 \mathrm{~d}$ (CS60:40; $n=7$ ), 2) $60 \%$ CS and $40 \%$ CO on DM basis fed for $42 \mathrm{~d}$ and $40 \% \mathrm{CS}$ and $60 \% \mathrm{CO}$ on DM basis fed for $42 \mathrm{~d}$ (CS reverse diet [CSR]; $n=7$ ), 3) $40 \% \mathrm{CS}$ and $60 \% \mathrm{CO}$ on DM basis fed for $84 \mathrm{~d}$ (CS40:60; $n=$ 7), 4) $60 \% \mathrm{SC}$ and $40 \% \mathrm{CO}$ on DM basis fed for $84 \mathrm{~d}$ (SC60:40; $n=7$ ), 5) $60 \% \mathrm{SC}$ and $40 \% \mathrm{CO}$ on DM basis fed for $42 \mathrm{~d}$ and $40 \% \mathrm{SC}$ and $60 \% \mathrm{CO}$ on DM basis fed for $42 \mathrm{~d}$ (SC reverse $\operatorname{diet}$ [SCR]; $n=7$ ), and 6) $40 \% \mathrm{SC}$ and $60 \% \mathrm{CO}$ on DM basis fed for $84 \mathrm{~d}(\mathbf{S C 4 0 : 6 0} ; n=7)$. At the end of the study, all bulls were weighed after a 16-h feed withdrawal period.

Corn silage was collected from a covered trenchtype silo (60 d of storing) $1 \mathrm{~h}$ before feeding, whereas SC was shredded to approximately $13 \mathrm{~mm}$ immediately before feeding. Dry matter contents from CS and SC were assessed daily to adjust the amount of urea and ammonium sulfate ( $\mathbf{U}+\mathbf{A S} ; 9: 1)$ supplied to the bulls, and the U+AS mixture was used to adjust CP content of the diets to $120 \mathrm{~g} / \mathrm{kg}$ DM $(19.2 \mathrm{~g}$ of nitrogen $/ \mathrm{kg}$ of $\mathrm{DM})$. The DM contents were assessed daily in duplicates, using a conventional microwave oven, according to recommendations from the National Forage Testing Association (1993).

The chemical compositions of the feeds used in the experimental diets are shown in Table 1 . The $\mathrm{CO}$ used in all diets consisted of $90.4 \%$ corn meal, $7.90 \%$ soybean meal, $0.85 \%$ mineral mixture, and $0.85 \% \mathrm{NaCl}$ ( $\%$ DM basis). The chemical composition of the CO (\% DM basis) was $97.3 \%$ OM, $12.6 \% \mathrm{CP}, 3.35 \%$ ether extract (EE), 14.0\% NDF, 67.3\% nonfiber carbohydrates (NFC), 3.31\% indigestible NDF (iNDF), 64.1\% starch, $3.07 \%$ water-soluble carbohydrate, $1.05 \%$ NDIN, and $0.01 \%$ ADIN. The compositions of the diets are shown in Table 2. The FA compositions ( $\%$ of total FA) of the roughages, $\mathrm{CO}$, and diets used in this experiment are presented in Table 3. 
Table 2. Feed and chemical composition of concentrate and diets used in the experiment

\begin{tabular}{lcccc}
\hline \hline & \multicolumn{3}{c}{ Corn silage } & \multicolumn{2}{c}{ Sugarcane } \\
\cline { 2 - 3 } \cline { 5 - 6 } Ingredient & 60.0 & 40.0 & 60.0 & 40.0 \\
\hline Forage & 36.2 & 54.2 & 36.2 & 54.2 \\
Corn & 3.16 & 4.74 & 3.16 & 4.74 \\
Soybean meal & 0.34 & 0.51 & 0.34 & 0.51 \\
Mineral mix & 0.34 & 0.51 & 0.34 & 0.51 \\
Salt & 2.06 & 2.06 & 3.49 & 3.49 \\
Urea + ammonium sulfate & Chemical composition, \% DM \\
Item & 95.8 & 96.3 & 97.4 & 96.3 \\
\hline OM & 12.5 & 12.9 & 11.8 & 12.9 \\
CP & 3.28 & 3.30 & 2.28 & 2.64 \\
Ether extract & 36.7 & 29.6 & 32.4 & 26.3 \\
NDF & 45.4 & 53.1 & 55.3 & 57.4 \\
Nonfiber carbohydrates & 9.76 & 7.54 & 14.5 & 10.7 \\
Indigestible NDF & 39.2 & 47.7 & 28.7 & 40.5 \\
Starch & 3.50 & 3.42 & 23.7 & 16.9 \\
Water-soluble carbohydrates & 20.2 & 14.9 & 22.1 & 16.2 \\
ADF & 1.40 & 1.28 & 0.46 & 0.66 \\
NDIN & 0.65 & 0.46 & 0.08 & 0.08 \\
ADIN & \multicolumn{3}{c}{}
\end{tabular}

The roughages (CS and SC) were supplied at 0800 $\mathrm{h}$ along with the mixture of U+AS and half of the daily quantity of $\mathrm{CO}$. At first, the mixture of $\mathrm{U}+\mathrm{AS}$ was incorporated into the roughage, and then the $\mathrm{CO}$ was mixed with the roughage. At $1500 \mathrm{~h}$, the other half of the CO was supplied to bulls. The amounts of roughage, $\mathrm{CO}$, and U+AS supplied as well as orts were recorded daily. To allow bulls ad libitum access to feed, feed delivery was adjusted to allow approximately $5 \%$ of orts daily. All bulls had ad libitum access to water. Roughages and orts were sampled daily and stored at $-20^{\circ} \mathrm{C}$ until analyses. Samples of each roughage and orts were combined weekly, dried in a forced-air oven $\left(55^{\circ} \mathrm{C}\right)$ for 72 $\mathrm{h}$, and ground through a 1-mm screen (Wiley mill; A. H. Thomas, Philadelphia, PA).

Dry matter content was determined using AOAC (2000) method number 934.01. A composite sample of orts proportional to the weekly DM was prepared for each 21-d period for each animal for further laboratory analyses.

\section{Apparent Digestibility}

For the evaluation of apparent digestibility coefficients, fecal samples from each bull were collected during the last $3 \mathrm{~d}$ of each period (Prates et al., 2012). Fecal samples were collected from the rectum at 0600, 1200, and $1800 \mathrm{~h}$ of Days 1, 2, and 3, respectively. Fecal samples were dried in a forced-air oven $\left(55^{\circ} \mathrm{C}\right)$ for $72 \mathrm{~h}$ and then ground to pass a 1-mm screen (Wiley mill; A. H. Thomas). A composite sample was prepared using $15 \mathrm{~g}$ of the dried and ground sample per time of collection for each bull.
Table 3. Fatty acid composition ( $\%$ of total fatty acids) of corn silage, sugarcane, concentrate, and diets used in the experimental diets

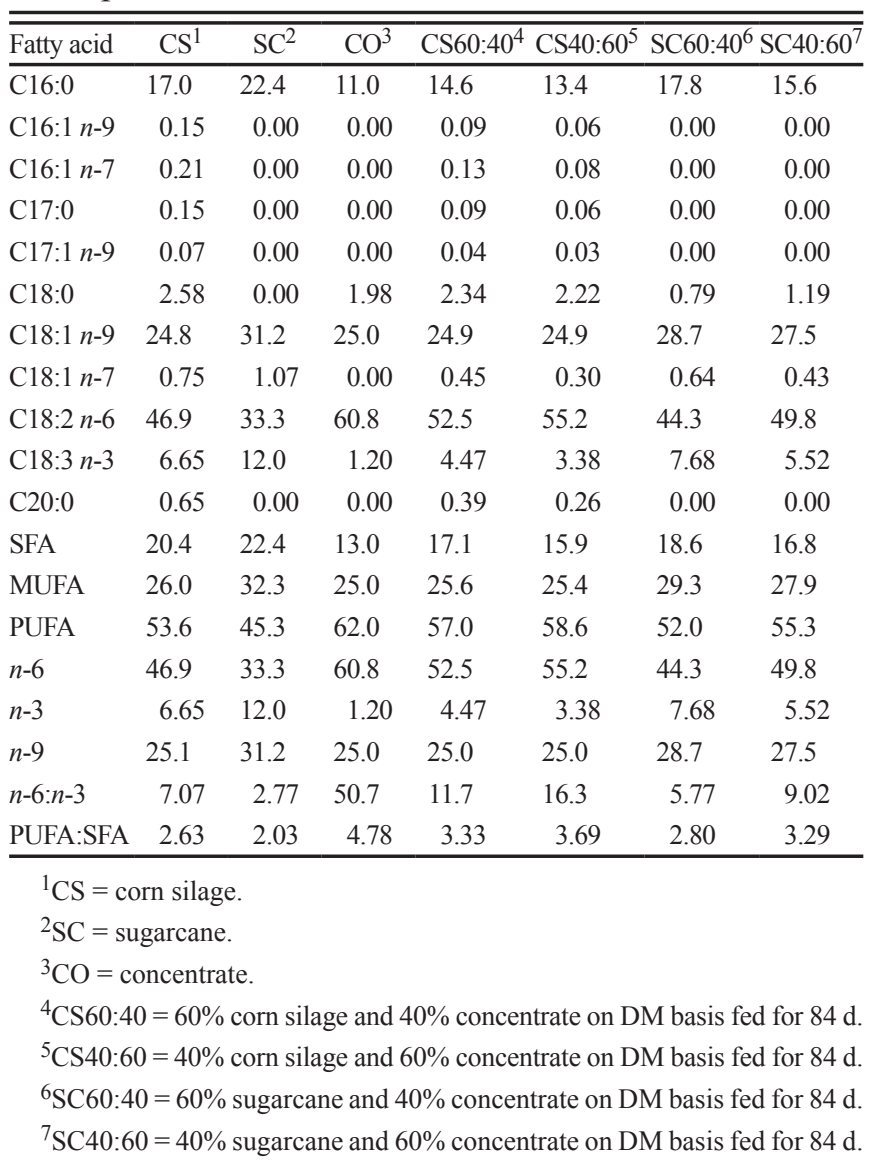

Indigestible NDF was used as an internal marker to estimate the fecal excretion (Lippke et al., 1986).

\section{Slaughter Procedure}

On d 114, all bulls were slaughtered in the facilities of Universidade Federal de Viçosa. Before slaughtering, bulls were fasted for $16 \mathrm{~h}$. After slaughtering, the carcass of each bull was divided in 2 half carcasses. The $\mathrm{pH}$ of left carcasses was measured at the exposed LM using a Meatcheck $160 \mathrm{pH}$ (Sigma Electronic GmbH Erfurt, Erfurt, Germany) equipped with a pH probe (LoT406M6-DXK-S7/25; Mettler-Toledo GmbH, Urdorf, Switzerland) approximately $45 \mathrm{~min}$ after slaughter.

The left half of the carcasses was weighed and cooled in a cold chamber at $4{ }^{\circ} \mathrm{C}$ for $24 \mathrm{~h}$. Twelve and $24 \mathrm{~h}$ after slaughter, $\mathrm{pH}$ measurements were obtained. After the 24-h chill, carcasses were weighed for evaluation of the cold carcass weight $(\mathbf{C C W})$, cold carcass dressing (CCD), and carcass length (CAL) at the height of the 12th rib.

After cooling, a LM sample of approximately $200 \mathrm{~g}$ was removed from between the 12th and 13th ribs to evaluate the chemical composition and the FA composition. 
The samples were vacuum packed and stored at $-20^{\circ} \mathrm{C}$ until further analyses.

\section{Laboratory Analyses}

For the laboratory analyses, LM samples were thawed at room temperature and ground for the determination of moisture, ash, and $\mathrm{CP}$ according to the methodology described by the AOAC (2012). The total lipid percentage was determined according to Bligh and Dyer (1959), and the triglyceride transesterification to obtain FA methyl esters was performed according to the International Organization for Standardization method (ISO, 1978). The FA methyl esters were analyzed by gas chromatography (Shimadzu GC-14A; Shimadzu Corp., Nakagyo-ku, Kyoto, Japan) equipped with a flame ionization detector and a fused silica capillary column (100 $\mathrm{m}$ long, $0.25 \mathrm{~mm}$ internal diameter, and $0.20 \mu \mathrm{m} \mathrm{CP}-$ Sil88; Chrompack, lanarkshire, United Kingdon). The gas flow rates were $1.2 \mathrm{~mL} / \mathrm{min}$ for the carrier gas $\left(\mathrm{H}_{2}\right)$, $30 \mathrm{~mL} / \mathrm{min}$ for the auxiliary gas $\left(\mathrm{N}_{2}\right), 30 \mathrm{~mL} / \mathrm{min}$ for the flame gas $\left(\mathrm{H}_{2}\right)$, and $300 \mathrm{~mL} / \mathrm{min}$ for synthetic air. The injector and detector temperatures were 220 and $245^{\circ} \mathrm{C}$, respectively. The column temperature was maintained at $180^{\circ} \mathrm{C}$ for $5 \mathrm{~min}$ and then raised to $240^{\circ} \mathrm{C}$ at a rate of $4^{\circ} \mathrm{C} / \mathrm{min}$. The sample split ratio was 1:100. The peak areas were determined according to the normalization method using a CG-300 computing integrator program, and the peaks were identified by comparisons with the retention times of standard FA methyl esters (SigmaAldrich, St. Louis, MO).

Samples of CS, SC, ingredients of the CO, orts, and feces were quantified for $\mathrm{DM}, \mathrm{OM}$, and $\mathrm{CP}$ (AOAC, 2012; method numbers 934.01, 930.05, and 981.10, respectively). Ether extract was analyzed according to the AOAC (2006; method number 945.16). Neutral detergent fiber was analyzed according to the technique described by Mertens et al. (2002), without the addition of sodium sulfite but with the addition of thermostable $\alpha$-amylase to the detergent (Ankom Technology Corp., Fairport, NY). The NDIN and ADIN followed the technique described by Licitra et al. (1996). Acid detergent fiber was determined by the method described by Van Soest et al. (1991).

The iNDF concentrations were determined in triplicates for samples of orts and feeds that were included in the experimental diets. The samples used for quantifying iNDF were ground through a 1-mm screen (Wiley mill; A. H. Thomas; Valente et al., 2011). For analysis, a 1-g sample and previously weighed F57 bags (Ankom Technology Corp.) with 95\% of the open area having pores of $25 \mu \mathrm{m}$ in size were used. Before starting the trial, we had 44 bulls and 2 bulls were randomly selected to receive rumen fistulas. These bulls received a mixed diet of $\mathrm{CS}, \mathrm{SC}$, and $\mathrm{CO}$ ad libitum during the trial and at the end of the experiment they were used for iNDF evaluation. The bags with the samples were incubated for $288 \mathrm{~h}$. Once removed from the rumen, the bags were washed with water and dried at $55^{\circ} \mathrm{C}$ for $48 \mathrm{~h}$ (Valente et al., 2011). Subsequently, NDF analyses were performed using an Ankom 200/220 fiber analyzer device (Ankom Technology Corp.).

Nonfiber carbohydrates were calculated according to Detmann and Valadares Filho (2010), where NFC (\% of $\mathrm{DM})=1,000-[\mathrm{CP}-(\mathrm{CP}$ derived from urea + urea $)+$ $\mathrm{NDF}+\mathrm{EE}+$ minerals $]$.

Starch concentration was analyzed according to method 7611 of the American Association of Cereal Chemists (2003) on a Roch Cobas Mira S instrument (Roche Diagnostics, Basel, Switzerland). Water-soluble carbohydrates in the forages were determined as described by Thomas (1977). The OM content of forages and effluents were analyzed by combusting the materials at $550^{\circ} \mathrm{C}$ for $6 \mathrm{~h}$ in a muffle furnace.

\section{Statistical Analyses}

The data referring to voluntary intake, animal performance, carcass characteristics, and FA composition were analyzed as completely randomized design, using PROC MIXED procedure (SAS Inst. Inc., Cary, NC). Diets were considered the fixed effects, and the animals were the random effect. Heterogeneous first-order autoregressive matrix (ARH [1]) was adopted; this was the variance and covariance matrix of random effects for all of the variables analyzed.

The data concerning digestibility, carcass $\mathrm{pH}$, and DMI were considered measurements repeated over time and were evaluated as mixed models through PROC MIXED procedure (SAS Inst. Inc.). The period was considered to be the fixed effect for digestibility and DMI, measuring time as the fixed effect for carcass $\mathrm{pH}$, and animals were considered the random effect. Distinct residual variances were modeled by using the command REPEATED. A ARH [1] was used. The PDIFF option adjusted by the Tukey method was included in the LSMEANS statement to account for multiple comparisons. Differences were declared significant at $P<0.05$. The level of tendency was set as $P<0.10$.

\section{RESULTS AND DISCUSSION}

\section{Dry Matter and Nutrient Intake}

Differences $(P<0.01)$ were observed in DMI in bulls fed CS- and SC-based diets. Dry matter intake was greater in bulls fed CS-based diets, regardless of the level of roughage supplied (Table 4). Intermediate values of DMI 
Table 4. Dry matter, nutrient intake (kg DM/d), and apparent digestibility (\%) for bulls fed corn silage or sugarcanebased diets for $84 \mathrm{~d}$

\begin{tabular}{|c|c|c|c|c|c|c|c|c|}
\hline \multirow[b]{2}{*}{ Item $^{1}$} & \multicolumn{6}{|c|}{ Diets } & \multirow[b]{2}{*}{ SEM } & \multirow[b]{2}{*}{$P$-value } \\
\hline & CS60:40 & $\mathrm{CSR}^{3}$ & CS40:604 & SC60:40 & $\mathrm{SCR}^{6}$ & SC40:607 & & \\
\hline \multicolumn{9}{|l|}{$\overline{\mathrm{DM}}$} \\
\hline Intake & $10.5^{\mathrm{a}}$ & $10.1^{\mathrm{a}}$ & $10.2^{\mathrm{a}}$ & $7.71^{\mathrm{c}}$ & $8.38^{\mathrm{b}}$ & $8.96^{\mathrm{b}}$ & 0.41 & $<0.01$ \\
\hline $\mathrm{AD}^{8}$ & $67.0^{\mathrm{b}}$ & $69.0^{\mathrm{b}}$ & $69.2^{\mathrm{b}}$ & $76.4^{\mathrm{a}}$ & $76.8^{\mathrm{a}}$ & $78.1^{\mathrm{a}}$ & 2.30 & $<0.01$ \\
\hline \multicolumn{9}{|l|}{$\mathrm{OM}$} \\
\hline Intake & $9.92^{\mathrm{a}}$ & $9.59^{\mathrm{a}}$ & $9.73^{\mathrm{a}}$ & $7.31^{\mathrm{c}}$ & $7.99^{b c}$ & $8.57^{\mathrm{ab}}$ & 0.35 & $<0.01$ \\
\hline Intake & $1.30^{\mathrm{a}}$ & $1.27^{\mathrm{a}}$ & $1.28^{\mathrm{a}}$ & $1.05^{\mathrm{b}}$ & $1.17^{\mathrm{b}}$ & $1.21^{\mathrm{ab}}$ & 0.11 & 0.03 \\
\hline $\mathrm{AD}$ & $66.6^{\mathrm{b}}$ & $66.4^{\mathrm{b}}$ & $65.9^{\mathrm{b}}$ & $76.0^{\mathrm{a}}$ & $76.4^{\mathrm{a}}$ & $75.9^{\mathrm{a}}$ & 2.40 & $<0.01$ \\
\hline \multicolumn{9}{|c|}{ Ether extract } \\
\hline Intake & $0.35^{\mathrm{a}}$ & $0.34^{\mathrm{a}}$ & $0.34^{\mathrm{a}}$ & $0.18^{\mathrm{c}}$ & $0.21^{\mathrm{bc}}$ & $0.23^{\mathrm{b}}$ & 0.17 & $<0.01$ \\
\hline $\mathrm{AD}$ & $78.6^{\mathrm{c}}$ & $79.6^{\mathrm{c}}$ & $77.6^{\mathrm{c}}$ & $84.6^{\mathrm{a}}$ & $79.2^{\mathrm{bc}}$ & $82.9^{\mathrm{ab}}$ & 2.60 & 0.04 \\
\hline \multicolumn{9}{|l|}{$\mathrm{NFC}^{9}$} \\
\hline Intake & $5.01^{\mathrm{ab}}$ & $5.23^{\mathrm{a}}$ & $5.52^{\mathrm{a}}$ & $4.41^{\mathrm{b}}$ & $5.00^{\mathrm{ab}}$ & $5.48^{\mathrm{a}}$ & 0.21 & $<0.01$ \\
\hline $\mathrm{AD}$ & $76.9^{b}$ & $76.2^{\mathrm{b}}$ & $72.3^{\mathrm{b}}$ & $88.2^{\mathrm{a}}$ & $85.7^{\mathrm{a}}$ & $87.0^{\mathrm{a}}$ & 2.20 & $<0.01$ \\
\hline \multicolumn{9}{|l|}{ TDN } \\
\hline Intake & $7.33^{\mathrm{a}}$ & $7.31^{\mathrm{a}}$ & $7.17^{\mathrm{a}}$ & $5.90^{\mathrm{c}}$ & $6.53^{b c}$ & $6.92^{\mathrm{ab}}$ & 0.74 & $<0.01$ \\
\hline
\end{tabular}

${ }^{1}$ Dry matter intake was determined at 42 and $84 \mathrm{~d}$ of trial. Nutrient intakes and digestibility were determined at $84 \mathrm{~d}$ of trial.

${ }^{2} \mathrm{CS} 60: 40=60 \%$ corn silage and $40 \%$ concentrate on DM basis fed for $84 \mathrm{~d}$.

${ }^{3} \mathrm{CSR}=\mathrm{CS}$ reverse diet: $60 \%$ corn silage and $40 \%$ concentrate on DM basis fed for $42 \mathrm{~d}$ and $40 \%$ corn silage and $60 \%$ concentrate on DM basis fed for $42 \mathrm{~d}$.

${ }^{4} \mathrm{CS} 40: 60=40 \%$ corn silage and $60 \%$ concentrate on DM basis fed for $84 \mathrm{~d}$.

${ }^{5} \mathrm{SC} 60: 40=60 \%$ sugarcane and 40\% concentrate on DM basis fed for $84 \mathrm{~d}$.

${ }^{6} \mathrm{SCR}=\mathrm{SC}$ reverse diet: $60 \%$ sugarcane and $40 \%$ concentrate on DM basis fed for $42 \mathrm{~d}$ and $40 \%$ sugarcane and $60 \%$ concentrate on DM basis fed for $42 \mathrm{~d}$.

${ }^{7} \mathrm{SC} 40: 60=40 \%$ sugarcane and 60\% concentrate on DM basis fed for $84 \mathrm{~d}$.

${ }^{8} \mathrm{AD}=$ apparent digestibility.

${ }^{9} \mathrm{NFC}=$ nonfiber carbohydrates.

were observed in bulls fed SCR and SC40:60 (Table 4). Bulls fed SC60:40 showed the lowest DMI (Table 4).

Differences $(P=0.03)$ were observed for CP intake in bulls fed CS- and SC-based diets. Crude protein intake was greater in bulls fed CS-based diets and SC40:60 than SC60:40, but no difference $(P=$ $0.25)$ was observed among SC-based diets (Table 4). Although SC has a low percentage of CP (Table 1), CP intake was adjusted for all diets. The difference in $\mathrm{CP}$ intake was therefore caused by the reduced DMI in bulls fed SC-based diets. Pinto et al. (2010) observed lower CP intake for animals fed SC than animals fed sorghum silage with different levels of CO. According to Magalhães et al. (2006), regardless of the feeding strategy used, forages of different qualities affect DMI and consequently the ingestion of dietary components.

Ether extract, NDF, NFC, and TDN intakes differed $(P<0.01)$ between the different diets provided. Ether extract intake was greater in bulls fed CS-based diets, regardless of the level of roughage used (Table 4). The lowest EE intake was observed in bulls fed SC60:40, but it did not differ from that obtained by animals fed SCR. Neutral detergent fiber intake was greatest in bulls fed CS60:40 (Table 4) followed by animals fed CSR and CS40:60, which had intermediate values. The lowest values for NDF intake were observed in bulls fed SC-based diets, regardless of the concentration of roughage supplied. The NFC intake was greater in bulls fed CSR, CS40:60, and SC40:60 as compared to SC60:40, with intermediate values for CS60:40 and SCR. The TDN intake was greater in bulls fed CS-based diets, regardless of the concentration of roughage used as compared to bulls fed SC60:40 and SCR.

Orskov and Hovell (1978) reported that the digestion rate of SC fiber is very low in the rumen and the accumulation of NDF limits voluntary intake. Furthermore, Oliveira et al. (2011) demonstrated that the rumen filling effect of the SC NDF is due to the indigestible fraction of NDF. This occurs even though there is greater degradation of the NDF potentially digestible fraction in relation to NDF from CS. Differences on DM, OM, CP, EE, NDF, and NFC intakes are related to the differences in iNDF concentration among the diets. Magalhães et al. (2006) studied 4 levels of CS to 
replace SC $(0,33.3,66.6$, and $100 \%)$ and observed that the ingestion and digestion rates were greater for $\mathrm{DM}$ and NDF, respectively, for CS-based diets than SC-based diets. Likewise, Menezes et al. (2011) using 60\% of roughage observed greater rates of ingestion and passage for DM and NDF in CS-based diets when compared with SCbased diets. This can explain the greater DMI in bulls fed CS-based diets presented in this experiment.

\section{Apparent Digestibility}

The apparent digestibility values of $\mathrm{DM}, \mathrm{OM}, \mathrm{CP}$, and NFC were greater $(P<0.01)$ in bulls fed SC-based diets, regardless of the concentration of roughage supplied, in relation to animals fed CS-based diets (Table 4). The lower ingestion of SC-based diets probably caused a greater retention time in the rumen, which could result in increased digestion.

The greatest $\mathrm{CP}$ digestibility observed for the SCbased diets may be explained by the greater quantity of urea supplied in these diets (SC) and by the synchrony of the urea hydrolysis with the degradation of NFC (Xin et al., 2010; Khattab et al., 2013). This better synchrony may be responsible for the increase in the efficiency of incorporation of NPN into microbial protein. Ribeiro et al. (2011) observed that the inclusion of NPN in low-CP diets for cattle increased CP digestibility. However, it is possible that the NPN was absorbed as ammonia and excreted in urine as urea, and consequently, the greater apparent CP digestibility was a reflection of a low total amount of nitrogen absorbed by the small intestine.

Differences $(P<0.01)$ in NDF digestibility were observed. The digestibility of NDF was greater in bulls fed CS60:40 (Table 4). The lowest values of NDF digestibility were observed for SC-based diets, regardless of the level of roughage used. Bulls fed CSR and CS40:60 showed similar NDF digestibility. These results can be explained by the level of roughage used, which in turn may be explained by the greatest iNDF concentration and intake of bulls fed SC-based diets (Menezes et al., 2011).

\section{Animal Performance}

Average daily gain was affected $(P<0.01)$ by treatments (Table 5). Bulls fed CS40:60 had greater $(P<$ $0.05)$ ADG in relation to those fed CS60:40 and SCbased diets. However, there was no difference $(P=0.52)$ for ADG between CS60:40, CSR, and SC40:60. Thus, $\mathrm{SC}$ can replace $\mathrm{CS}$ in diets for feedlot-finished crossbred Holstein $\times$ Zebu bulls without negatively impacting $\mathrm{ADG}$, if $20 \%$ more $\mathrm{CO}$ is added to the diet.

The SCR diet was not effective to maintain ADG comparable to bulls fed SC40:60 (Table 5). However, greater $(P<0.01)$ ADG $(1.28$ vs. $1.00 \mathrm{~kg} / \mathrm{d})$ was observed for
SCR in relation to SC60:40. Thus, SCR increased ADG in bulls fed SC60:40. The reverse diet can be an alternative feeding protocol by feedlots to increase ADG at the end of the finishing period and thus reduce the amount of time required for bulls to reach harvest weight.

The G:F was greater $(P<0.01)$ in bulls fed CS40:60, CSR, and SC40:60 than SC60:40 (Table 5). However, no difference $(P=0.69)$ was observed to $\mathrm{G}: \mathrm{F}$ among bulls fed CS60:40, CSR, SCR, and SC40:60. The lowest $(P<$ $0.01)$ value to G:F was observed in bulls fed SC60:40. Our data suggest that the SC40:60 diet can be used in bulls finished in feedlots without altering the feed efficiency when compared to bulls fed CS-based diets.

The nutrient requirements for $\mathrm{ME}$ and $\mathrm{CP}$ calculated according to Rotta et al. (2013) are presented in Table 5 According to the nutrient requirements and the ME and $\mathrm{CP}$ intakes, it is possible to verify that the nutrient balance in this study was positive for all treatments evaluated. However, for CP, the balance was 0.00 for all treatments, except for CSR and CS40:60 (values for these treatments were negative but close to 0.00 ). We hypothesize that increasing $\mathrm{CP}$ in the diet would increase the animal growth.

\section{Carcass Characteristics}

Cold carcass weight and HCW were greater $(P<$ $0.05)$ in bulls fed CS-based diets than those fed SCbased diets (Table 5). The greater $\mathrm{CCW}$ and $\mathrm{HCW}$ in bulls fed CS-based diets may be due to the greater ADG and carcass dressing percentage observed for these animals in relation to those fed SC-based diets. The 12thrib fat was greater $(P=0.03)$ in bulls fed CSR than bulls fed other diets (Table 5).

No difference was observed $(P=0.28)$ for CAL in bulls fed CS-based diets or SC-based diets (Table 5). Hot carcass dressing (HCD) percentage showed a tendency $(P=0.09)$ for greater values in bulls fed CS-based diets. There was a difference $(P<0.05)$ in CCD percentage (Table 5). Bulls fed CS-based diets, regardless of the level of roughage, had greater $(P=0.03) \mathrm{CCD}$ than those fed SC-based diets. This demonstrates that CSbased diets improve both HCD and CCD as compared to SC-based diets. Wilcox et al. (1953) observed that beef cattle fed with sucrose at least $30 \mathrm{~h}$ before slaughter had decreased HCD. Our findings may result from having a greater concentration of sucrose from SC. Dietary treatment did not affect $(P>0.10)$ carcass $\mathrm{pH}$ at any of the times evaluated (Table 5).

\section{Chemical Composition}

The different diets did not influence $(P>0.75)$ the chemical composition ( $\%$ of total LM) in crossbred bulls (Table 6). 
Table 5. Animal performance, nutrient balance, and carcass characteristics of bulls fed corn silage or sugarcane-based diets for $84 \mathrm{~d}$

\begin{tabular}{|c|c|c|c|c|c|c|c|c|}
\hline \multirow[b]{2}{*}{ Item } & \multicolumn{6}{|c|}{ Diets } & \multirow[b]{2}{*}{ SEM } & \multirow[b]{2}{*}{$P$-value } \\
\hline & CS60:40 1 & $\mathrm{CSR}^{2}$ & $\mathrm{CS} 40: 60^{3}$ & SC60:40 4 & $\mathrm{SCR}^{5}$ & SC40:606 & & \\
\hline \multicolumn{9}{|l|}{ Animal performance } \\
\hline Initial BW, kg & 357 & 348 & 336 & 352 & 330 & 334 & 15.4 & 0.79 \\
\hline Final BW, kg & 489 & 484 & 486 & 436 & 438 & 453 & 16.7 & 0.16 \\
\hline DMI, kg & $10.5^{\mathrm{a}}$ & $10.1^{\mathrm{a}}$ & $10.2^{\mathrm{a}}$ & $7.71^{\mathrm{c}}$ & $8.38^{\mathrm{b}}$ & $8.96^{\mathrm{b}}$ & 0.41 & $<0.01$ \\
\hline $\mathrm{ADG}, \mathrm{kg}$ & $1.58^{\mathrm{b}}$ & $1.63^{\mathrm{ab}}$ & $1.79^{\mathrm{a}}$ & $1.00^{\mathrm{d}}$ & $1.28^{\mathrm{c}}$ & $1.42^{\mathrm{b}}$ & 0.25 & $<0.01$ \\
\hline CP intake, $\mathrm{g} / \mathrm{d}$ & $1.30^{\mathrm{a}}$ & $1.27^{\mathrm{a}}$ & $1.28^{\mathrm{a}}$ & $1.05^{\mathrm{b}}$ & $1.17^{\mathrm{b}}$ & $1.21^{\mathrm{ab}}$ & 0.11 & 0.03 \\
\hline \multicolumn{9}{|l|}{ Nutrient requirements ${ }^{7}$} \\
\hline ME, Mcal/d & 24.7 & 24.9 & 25.4 & 19.9 & 22.3 & 23.5 & - & - \\
\hline $\mathrm{CP}, \mathrm{g} / \mathrm{d}$ & 1.30 & 1.31 & 1.36 & 1.05 & 1.17 & 1.21 & - & - \\
\hline \multicolumn{9}{|l|}{ Nutrient balance } \\
\hline Cold carcass weight, $\mathrm{kg}$ & $276^{\mathrm{a}}$ & $277^{\mathrm{a}}$ & $280^{\mathrm{a}}$ & $235^{\mathrm{b}}$ & $242^{b}$ & $249^{b}$ & 9.80 & 0.02 \\
\hline $\mathrm{HCW}, \mathrm{kg}$ & $282^{\mathrm{a}}$ & $283^{\mathrm{a}}$ & $285^{\mathrm{a}}$ & $241^{\mathrm{b}}$ & $248^{\mathrm{b}}$ & $256^{\mathrm{b}}$ & 7.90 & 0.03 \\
\hline 12th-rib fat, mm & $1.58^{\mathrm{b}}$ & $2.78^{\mathrm{a}}$ & $1.85^{\mathrm{b}}$ & $1.20^{\mathrm{b}}$ & $1.48^{\mathrm{b}}$ & $1.79^{\mathrm{b}}$ & 0.29 & 0.03 \\
\hline Carcass length, cm & 136 & 133 & 131 & 132 & 135 & 131 & 5.41 & 0.28 \\
\hline Hot carcass dressing, $\%$ & $56.4^{\mathrm{a}}$ & $57.3^{\mathrm{a}}$ & $57.5^{\mathrm{a}}$ & $54.7^{\mathrm{b}}$ & $55.0^{\mathrm{b}}$ & $55.4^{\mathrm{b}}$ & 2.65 & 0.09 \\
\hline Cold carcass dressing, $\%$ & $55.2^{\mathrm{a}}$ & $56.1^{\mathrm{a}}$ & $56.5^{\mathrm{a}}$ & $53.4^{\mathrm{b}}$ & $53.6^{\mathrm{b}}$ & $53.9^{\mathrm{b}}$ & 1.48 & 0.03 \\
\hline $\mathrm{pH} 45 \mathrm{~min}$ & 7.21 & 7.16 & 7.25 & 7.14 & 7.32 & 7.35 & 1.02 & 0.37 \\
\hline $\mathrm{pH} 12 \mathrm{~h}$ & 6.50 & 6.23 & 6.15 & 6.57 & 6.45 & 6.41 & 0.84 & 0.29 \\
\hline $\mathrm{pH} 24 \mathrm{~h}$ & 6.59 & 6.55 & 6.35 & 6.44 & 6.46 & 6.46 & 0.92 & 0.99 \\
\hline
\end{tabular}

${ }^{1} \mathrm{CS} 60: 40=60 \%$ corn silage and $40 \%$ concentrate on DM basis fed for $84 \mathrm{~d}$.

${ }^{2} \mathrm{CSR}=\mathrm{CS}$ reverse diet: $60 \%$ corn silage and $40 \%$ concentrate on DM basis fed for $42 \mathrm{~d}$ and $40 \%$ corn silage and $60 \%$ concentrate on DM basis fed for $42 \mathrm{~d}$. ${ }^{3} \mathrm{CS} 40: 60=40 \%$ corn silage and $60 \%$ concentrate on DM basis fed for $84 \mathrm{~d}$.

${ }^{4}$ SC60:40 $=60 \%$ sugarcane and 40\% concentrate on DM basis fed for $84 \mathrm{~d}$.

${ }^{5} \mathrm{SCR}=$ SC reverse diet: $60 \%$ sugarcane and $40 \%$ concentrate on DM basis fed for $42 \mathrm{~d}$ and $40 \%$ sugarcane and $60 \%$ concentrate on DM basis fed for $42 \mathrm{~d}$. ${ }^{6} \mathrm{SC} 40: 60=40 \%$ sugarcane and 60\% concentrate on DM basis fed for $84 \mathrm{~d}$.

${ }^{7}$ Calculated using equations developed by Rotta et al. (2013).

According to previous studies (Prado et al., 2008a; Rotta et al., 2009; Oliveira et al., 2012; Freitas et al., 2014), the chemical composition of meat is only slightly influenced by diet. Prado et al. (2008a) evaluated the inclusion of linseed and soybean in 2 different periods in the experiment, and no effects were observed to chemi- cal composition of LM in bulls. Likewise, Rotta et al. (2009) reviewed factors affecting chemical composition in LM of cattle raised in Brazil and no differences were found. Freitas et al. (2014) evaluated the chemical composition of the meat of Hereford and Braford steers finished on pasture or in a feedlot and no difference was

Table 6. Chemical composition (\% total weight) in the LM of bulls fed corn silage or sugarcane-based diets for $84 \mathrm{~d}$

\begin{tabular}{|c|c|c|c|c|c|c|c|c|}
\hline \multirow[b]{2}{*}{ Item } & \multicolumn{6}{|c|}{ Diets } & \multirow[b]{2}{*}{ SEM } & \multirow[b]{2}{*}{$P$-value } \\
\hline & CS60:40 1 & $\mathrm{CSR}^{2}$ & $\mathrm{CS} 40: 60^{3}$ & SC60:40 & $\mathrm{SCR}^{5}$ & SC40:606 & & \\
\hline Moisture & 75.2 & 75.9 & 75.3 & 75.6 & 75.1 & 76.1 & 1.23 & 0.99 \\
\hline Ash & 0.93 & 0.91 & 0.93 & 0.91 & 0.93 & 0.93 & 0.33 & 0.99 \\
\hline $\mathrm{CP}$ & 20.1 & 19.7 & 19.6 & 19.9 & 20.2 & 19.4 & 0.98 & 0.77 \\
\hline Total lipids & 1.41 & 1.43 & 1.24 & 1.29 & 1.67 & 1.19 & 0.14 & 0.75 \\
\hline
\end{tabular}

${ }^{1} \mathrm{CS} 60: 40=60 \%$ corn silage and $40 \%$ concentrate on DM basis fed for $84 \mathrm{~d}$.

${ }^{2} \mathrm{CSR}=\mathrm{CS}$ reverse diet: $60 \%$ corn silage and $40 \%$ concentrate on DM basis fed for $42 \mathrm{~d}$ and $40 \%$ corn silage and $60 \%$ concentrate on DM basis fed for $42 \mathrm{~d}$. ${ }^{3} \mathrm{CS} 40: 60=40 \%$ corn silage and $60 \%$ concentrate on DM basis fed for $84 \mathrm{~d}$.

${ }^{4} \mathrm{SC} 60: 40=60 \%$ sugarcane and $40 \%$ concentrate on DM basis fed for $84 \mathrm{~d}$.

${ }^{5} \mathrm{SCR}=\mathrm{SC}$ reverse diet: $60 \%$ sugarcane and $40 \%$ concentrate on DM basis fed for $42 \mathrm{~d}$ and $40 \%$ sugarcane and $60 \%$ concentrate on DM basis fed for $42 \mathrm{~d}$. ${ }^{6} \mathrm{SC} 40: 60=40 \%$ sugarcane and $60 \%$ concentrate on DM basis fed for $84 \mathrm{~d}$. 
Table 7. Fatty acid composition (\% total fatty acids) in the LM of bulls fed corn silage or sugarcane-based diets for $84 \mathrm{~d}$

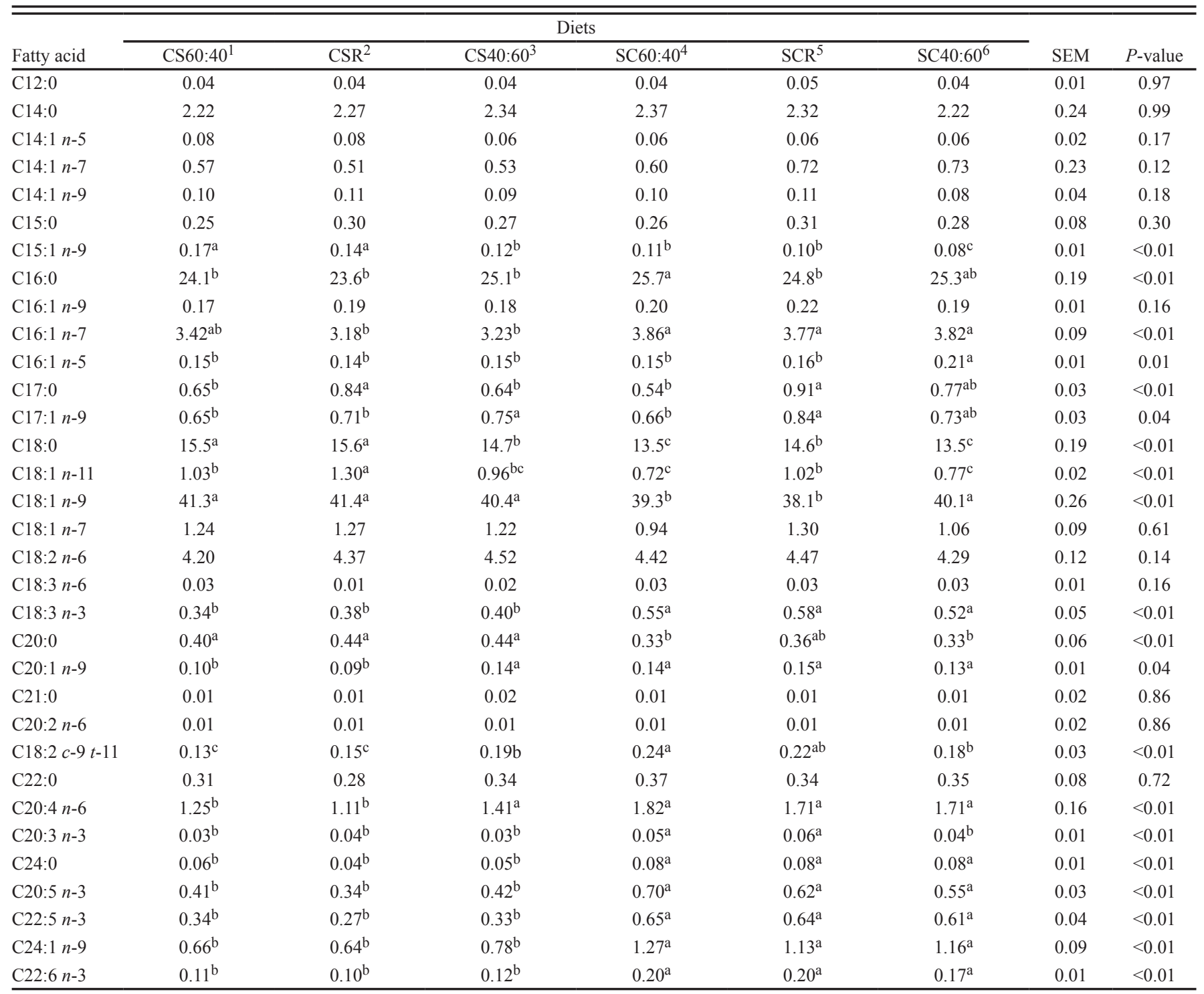

${ }^{1} \mathrm{CS} 60: 40=60 \%$ corn silage and $40 \%$ concentrate on DM basis fed for $84 \mathrm{~d}$.

${ }^{2} \mathrm{CSR}=\mathrm{CS}$ reverse diet: $60 \%$ corn silage and $40 \%$ concentrate on DM basis fed for $42 \mathrm{~d}$ and $40 \%$ corn silage and $60 \%$ concentrate on DM basis fed for $42 \mathrm{~d}$. ${ }^{3} \mathrm{CS} 40: 60=40 \%$ corn silage and $60 \%$ concentrate on DM basis fed for $84 \mathrm{~d}$.

${ }^{4} \mathrm{SC} 60: 40=60 \%$ sugarcane and 40\% concentrate on DM basis fed for $84 \mathrm{~d}$.

${ }^{5} \mathrm{SCR}=\mathrm{SC}$ reverse diet: $60 \%$ sugarcane and $40 \%$ concentrate on DM basis fed for $42 \mathrm{~d}$ and $40 \%$ sugarcane and $60 \%$ concentrate on DM basis fed for $42 \mathrm{~d}$. ${ }^{6} \mathrm{SC} 40: 60=40 \%$ sugarcane and $60 \%$ concentrate on DM basis fed for $84 \mathrm{~d}$.

observed. However, the inclusion of different oil types in the $\mathrm{CO}$ portion of the diet can be used to alter muscle lipid composition and moisture (Oliveira et al., 2012).

\section{Fatty Acid Composition}

Different diets did not affect $\mathrm{C} 12: 0(P=0.97)$ and C14:0 $(P=0.99)$ contents in LM (Table 7). These results have important implications for human health, because according to Woollett et al. (1992), these FA interfere with the normal function of low-density lipoprotein (LDL) receptors in the liver, which reduces LDL removal and increases its concentration in plasma.
The FA C14:1 $n-5(P=0.17), \mathrm{C} 14: 1 n-7(P=0.12)$, C14:1 $n-9(P=0.18), \mathrm{C} 15: 0(P=0.30), \mathrm{C} 16: 1 n-9(P=$ $0.16), \mathrm{C} 18: 1 n-7(P=0.61), \mathrm{C} 18: 2 n-6(P=0.14), \mathrm{C} 18: 3$ $n-6(P=0.16), 21: 0(P=0.86), \mathrm{C} 20: 2 n-6(P=0.86)$, and $\mathrm{C} 22: 0(P=0.72)$ were not influenced by the different diets studied (Table 7).

Although CS-based diets provided greater $(P<$ $0.01)$ intake of $\mathrm{C} 16: 0(\mathrm{~g} / \mathrm{d})$ than SC-based diets (Table $8)$, a greater $(P<0.01)$ percentage of the $\mathrm{C} 16: 0$ was observed in the LM of bulls fed SC60:40 than those fed CS-based diets (Table 7). However, no differences $(P>$ $0.10)$ were observed for SC40:60 and SC60:40. Palmitic acid (C16:0) is considered a hypercholesterolemic FA 
Table 8. Fatty acid intake (g/d) in bulls fed corn silage or sugarcane-based diets for $84 \mathrm{~d}$

\begin{tabular}{|c|c|c|c|c|c|c|c|c|}
\hline \multirow[b]{2}{*}{ Fatty acid } & \multicolumn{6}{|c|}{ Diets } & \multirow[b]{2}{*}{ SEM } & \multirow[b]{2}{*}{$P$-value } \\
\hline & CS60:40 1 & $\mathrm{CSR}^{2}$ & CS40:603 & SC60:40 & $\mathrm{SCR}^{5}$ & SC40:60 6 & & \\
\hline$\overline{\mathrm{C} 16: 0}$ & $51.1^{\mathrm{a}}$ & $47.6^{\mathrm{b}}$ & $45.6^{\mathrm{b}}$ & $32.0^{\mathrm{d}}$ & $35.1^{\mathrm{c}}$ & $35.9^{\mathrm{c}}$ & 2.21 & $<0.01$ \\
\hline $\mathrm{C} 16: 1 n-9$ & $0.32^{\mathrm{a}}$ & $0.26 \mathrm{a}^{\mathrm{b}}$ & $0.20^{\mathrm{b}}$ & $0.00^{\mathrm{c}}$ & $0.00^{\mathrm{c}}$ & $0.00^{\mathrm{c}}$ & 0.02 & $<0.01$ \\
\hline $\mathrm{C} 16: 1 n-7$ & $0.46^{\mathrm{a}}$ & $0.36^{\mathrm{b}}$ & $0.27^{\mathrm{c}}$ & $0.00^{\mathrm{d}}$ & $0.00^{\mathrm{d}}$ & $0.00^{\mathrm{d}}$ & 0.02 & $<0.01$ \\
\hline $\mathrm{C} 17: 0$ & $0.32^{\mathrm{a}}$ & $0.26^{\mathrm{b}}$ & $0.20^{\mathrm{c}}$ & $0.00^{\mathrm{d}}$ & $0.00^{\mathrm{d}}$ & $0.00^{\mathrm{d}}$ & 0.02 & $<0.01$ \\
\hline $\mathrm{C} 17: 1 n-9$ & $0.14^{\mathrm{a}}$ & $0.12^{\mathrm{ab}}$ & $0.10^{\mathrm{b}}$ & $0.00^{\mathrm{c}}$ & $0.00^{\mathrm{c}}$ & $0.00^{\mathrm{c}}$ & 0.01 & $<0.01$ \\
\hline $\mathrm{C} 18: 1 n-7$ & $1.58^{\mathrm{a}}$ & $1.28^{\mathrm{a}}$ & $1.02^{\mathrm{b}}$ & $1.15^{\mathrm{b}}$ & $1.12^{\mathrm{b}}$ & $0.99^{\mathrm{b}}$ & 0.10 & $<0.01$ \\
\hline $\mathrm{C} 18: 2 n-6$ & $183.8^{\mathrm{a}}$ & $183.1^{\mathrm{a}}$ & $187.7^{\mathrm{a}}$ & $79.7^{\mathrm{d}}$ & $98.8^{\mathrm{c}}$ & $114.5^{\mathrm{b}}$ & 4.21 & $<0.01$ \\
\hline $\mathrm{C} 18: 3 n-3$ & $15.7^{\mathrm{a}}$ & $13.4^{\mathrm{b}}$ & $11.5^{\mathrm{c}}$ & $13.8^{\mathrm{b}}$ & $13.9^{\mathrm{b}}$ & $12.7^{\mathrm{b}}$ & 0.54 & $<0.01$ \\
\hline $\mathrm{C} 20: 0$ & $1.37^{\mathrm{a}}$ & $1.11^{\mathrm{b}}$ & $0.88^{\mathrm{c}}$ & $0.00^{\mathrm{d}}$ & $0.00^{\mathrm{d}}$ & $0.00^{\mathrm{d}}$ & 0.2 & $<0.01$ \\
\hline $\mathrm{SFA}^{7}$ & $61.0^{\mathrm{a}}$ & $56.7^{b}$ & $54.2^{\mathrm{b}}$ & $33.5^{\mathrm{d}}$ & $37.2^{\mathrm{c}}$ & $38.6^{\mathrm{c}}$ & 2.01 & $<0.01$ \\
\hline$n-3$ & $15.7^{\mathrm{a}}$ & $13.4^{\mathrm{ab}}$ & $11.5^{\mathrm{c}}$ & $13.8^{\mathrm{a}}$ & $13.9^{\mathrm{a}}$ & $12.7^{\mathrm{b}}$ & 0.49 & $<0.01$ \\
\hline$n-9$ & $87.6^{\mathrm{a}}$ & $85.0^{\mathrm{a}}$ & $85.0^{\mathrm{a}}$ & $51.7^{\mathrm{c}}$ & $59.0^{\mathrm{b}}$ & $63.3^{\mathrm{b}}$ & 2.11 & $<0.01$ \\
\hline \multicolumn{9}{|c|}{${ }^{1}$ CS60:40 $=60 \%$ corn silage and $40 \%$ concentrate on DM basis fed for $84 \mathrm{~d}$} \\
\hline \multicolumn{9}{|c|}{${ }^{2} \mathrm{CSR}=\mathrm{CS}$ reverse diet: $60 \%$ corn silage and $40 \%$ concentrate on DM basis fed for $42 \mathrm{~d}$ and $40 \%$ corn silage and $60 \%$ concentrate on DM basis fed for $42 \mathrm{~d}$} \\
\hline \multicolumn{9}{|c|}{${ }^{3} \mathrm{CS} 40: 60=40 \%$ corn silage and $60 \%$ concentrate on DM basis fed for $84 \mathrm{~d}$} \\
\hline \multicolumn{9}{|c|}{${ }^{4} \mathrm{SC} 60: 40=60 \%$ sugarcane and $40 \%$ concentrate on DM basis fed for $84 \mathrm{~d}}$. \\
\hline \multirow{2}{*}{\multicolumn{9}{|c|}{$\begin{array}{l}{ }^{5} \mathrm{SCR}=\mathrm{SC} \text { reverse diet: } 60 \% \text { sugarcane and } 40 \% \text { concentrate on DM basis fed for } 42 \mathrm{~d} \text { and } 40 \% \text { sugarcane and } 60 \% \text { concentrate on DM basis fed for } 42 \mathrm{~d} \text {. } \\
{ }^{6} \mathrm{SC} 40: 60=40 \% \text { sugarcane and } 60 \% \text { concentrate on DM basis fed for } 84 \mathrm{~d} .\end{array}$}} \\
\hline & & & & & & & & \\
\hline \multicolumn{9}{|c|}{${ }^{7} \mathrm{SFA}$ is the sum of $\mathrm{C} 16: 0, \mathrm{C} 17: 0, \mathrm{C} 18: 0$, and $\mathrm{C} 20: 0$} \\
\hline \multicolumn{9}{|c|}{${ }^{8}$ MUFA is the sum of C16:1 n-9, C16:1 n-7, C17:1 n-9, C18:1 n-9, and C18:1 n-7. } \\
\hline
\end{tabular}

because it contributes to increase the amount of LDL (Souza and Visentainer, 2006; McNeill et al., 2012). In cattle, C16:0 is one of the most abundant FA, representing approximately $25 \%$ of the total FA content in muscle (Prado et al., 2008a,b).

The greatest $(P<0.01)$ percentage of $\mathrm{C} 18: 0$ was observed in bulls fed CS60:40 and CSR (Table 7), which may result from the greater intake $(P<0.01)$ of $\mathrm{C} 18: 0$ observed in bulls fed CS60:40 and CSR (Table 8). The SC60:40 and SC40:60 diets resulted in the lowest $(P<$ 0.01) C18:0 FA values. Although C18:0 is a SFA, current research suggests its effects on the markers of cardiovascular health may be neutral (Hunter et al., 2010). In our study, the concentration of $\mathrm{C} 18: 0$ ranges between 13.5 and $15.5 \%$, in agreement with the value of $13.0 \%$ of total FA reported by Buchanan et al. (2013).

The percentage of the C18:1 n-9 was greater $(P<$ 0.01) in the LM of bulls fed CS-based diets and SC40:60 (Table 7). C18:1 n-9 is the most abundant FA found in the LM of bulls (Prado et al., 2008a,b; Rotta et al., 2009). The greatest $(P<0.01)$ intake of $C 18: 1 n-9$ was also observed in bulls fed CS-based diets (Table 8). We can therefore infer that elevated C18:1 n-9 intake may be responsible for a greater LM deposition of this FA.
The EFA are not produced by the human body and must be acquired through the diet (Campbell, 1999). These FA can be found in beef (Prado et al., 2008a,b; Rotta et al., 2009; Valero et al., 2011) and can perform an important function of the body's immune response by acting as carriers of the soluble vitamins, including vitamins A, D, E, and K (Campbell, 1999). Moreover, EFA are linked to the prevention of coronary artery disease, hypertension, arthritis, diabetes, cancer, and inflammatory and autoimmune disorders (Simopoulos, 1999; Delgado-Lista et al., 2012).

According to Smith (2008), C18:2 n-6 and C18:3 $n-3$ are EFA. The C20:5 n-3, C20:4 n-6, and C22:6n-3 FA are considered semi-essential because endogenous synthesis is considered insufficient. In the presence of C18:2 n-6 and C18:3 n-3 FA, however, the C20:4 n-6 and $\mathrm{C} 22: 6 n-3$ FA are produced by the action of the delta-4, delta-5, and delta-6 desaturase enzymes (Souza and Visentainer, 2006).

The C18:3n-3 was the only $n$ - 3 FA found in the diets (Table 3 ), and its greatest $(P<0.01)$ intake was observed in bulls fed CS60:40 (Table 8). No difference $(P=0.29)$ was observed between SC-based diets and CSR intakes. Despite the greatest C18:3n-3 intake of the CS60:40 diet, the percentage of $\mathrm{C} 18: 3 n-3$ was greater $(P<0.01)$ in the 
Table 9. Sums, ratios, and quantification of fatty acids in the LM of bulls fed corn silage or sugarcane-based diets for $84 \mathrm{~d}$

\begin{tabular}{|c|c|c|c|c|c|c|c|c|}
\hline \multirow[b]{2}{*}{ Item } & \multicolumn{6}{|c|}{ Diets $^{1}$} & \multirow[b]{2}{*}{ SEM } & \multirow[b]{2}{*}{$P$-value } \\
\hline & CS60:40 1 & $\mathrm{CSR}^{2}$ & $\mathrm{CS} 40: 60^{3}$ & SC60:40 4 & $\mathrm{SCR}^{5}$ & SC40:60 ${ }^{6}$ & & \\
\hline $\mathrm{SFA},{ }^{7} \%$ & 43.5 & 42.4 & 43.4 & 43.2 & 43.8 & 42.9 & 1.21 & 0.66 \\
\hline MUFA, ${ }^{8} \%$ & $49.6^{\mathrm{a}}$ & $49.9^{\mathrm{a}}$ & $49.8^{\mathrm{a}}$ & $48.1^{\mathrm{b}}$ & $47.7^{\mathrm{b}}$ & $49.0^{\mathrm{ab}}$ & 0.84 & $<0.01$ \\
\hline PUFA, ${ }^{9} \%$ & $6.85^{\mathrm{c}}$ & $7.73^{b}$ & $6.83^{\mathrm{c}}$ & $8.67^{\mathrm{a}}$ & $8.54^{\mathrm{a}}$ & $8.11^{\mathrm{ab}}$ & 0.17 & $<0.01$ \\
\hline$n-6, \%$ & $5.49^{\mathrm{b}}$ & $6.22^{\mathrm{a}}$ & $5.65^{\mathrm{b}}$ & $6.28^{\mathrm{a}}$ & $6.22^{\mathrm{a}}$ & $6.04^{\mathrm{a}}$ & 0.24 & $<0.05$ \\
\hline$n-3, \%$ & $1.23^{\mathrm{b}}$ & $1.30^{\mathrm{b}}$ & $1.13^{\mathrm{b}}$ & $2.15^{\mathrm{a}}$ & $2.10^{\mathrm{a}}$ & $1.89^{\mathrm{a}}$ & 0.08 & $<0.01$ \\
\hline PUFA:SFA & $0.16^{\mathrm{b}}$ & $0.18^{\mathrm{ab}}$ & $0.16^{\mathrm{b}}$ & $0.20^{\mathrm{a}}$ & $0.20^{\mathrm{a}}$ & $0.19^{\mathrm{a}}$ & 0.02 & 0.04 \\
\hline $\mathrm{C} 12: 0, \mathrm{mg} / \mathrm{g}$ muscle & 0.36 & 0.38 & 0.41 & 0.39 & 0.36 & 0.35 & 0.12 & 0.54 \\
\hline C18:2 n-6, mg/g muscle & $35.6^{\mathrm{c}}$ & $34.2^{\mathrm{c}}$ & $43.2^{\mathrm{b}}$ & $54.7^{\mathrm{a}}$ & $52.5^{\mathrm{a}}$ & $46.4^{\mathrm{b}}$ & 1.33 & $<0.01$ \\
\hline C18:3 n-3, mg/g muscle & $2.96^{\mathrm{b}}$ & $3.30^{\mathrm{b}}$ & $3.33^{b}$ & $4.78^{\mathrm{a}}$ & $4.81^{\mathrm{a}}$ & $4.84^{\mathrm{a}}$ & 0.13 & $<0.01$ \\
\hline C18:2 c-9 $t-11, \mathrm{mg} / \mathrm{g}$ muscle & $1.12^{\mathrm{c}}$ & $1.31^{\mathrm{bc}}$ & $1.52^{\mathrm{b}}$ & $2.11^{\mathrm{a}}$ & $1.95^{\mathrm{a}}$ & $1.44^{\mathrm{b}}$ & 0.07 & $<0.01$ \\
\hline
\end{tabular}

${ }^{1} \mathrm{CS} 60: 40=60 \%$ corn silage and $40 \%$ concentrate on DM basis fed for $84 \mathrm{~d}$.

${ }^{2} \mathrm{CSR}=\mathrm{CS}$ reverse diet: $60 \%$ corn silage and $40 \%$ concentrate on DM basis fed for $42 \mathrm{~d}$ and $40 \%$ corn silage and $60 \%$ concentrate on DM basis fed for $42 \mathrm{~d}$.

${ }^{3} \mathrm{CS} 40: 60=40 \%$ corn silage and $60 \%$ concentrate on DM basis fed for $84 \mathrm{~d}$.

${ }^{4}$ SC60:40 $=60 \%$ sugarcane and $40 \%$ concentrate on DM basis fed for $84 \mathrm{~d}$.

${ }^{5} \mathrm{SCR}=$ SC reverse diet: $60 \%$ sugarcane and $40 \%$ concentrate on DM basis fed for $42 \mathrm{~d}$ and $40 \%$ sugarcane and $60 \%$ concentrate on DM basis fed for $42 \mathrm{~d}$.

${ }^{6} \mathrm{SC} 40: 60=40 \%$ sugarcane and $60 \%$ concentrate on DM basis fed for $84 \mathrm{~d}$.

${ }^{7} \mathrm{SFA}$ is the sum of $\mathrm{C} 12: 0, \mathrm{C} 14: 0, \mathrm{C} 15: 0, \mathrm{C} 16: 0, \mathrm{C} 17: 0, \mathrm{C} 18: 0, \mathrm{C} 20: 0, \mathrm{C} 21: 0, \mathrm{C} 22: 0$, and $\mathrm{C} 24: 0$.

${ }^{8}$ MUFA is the sum of C14:1 n-5, C14:1 n-7, C14:1 n-9, C15:1 n-9, C16:1 n-9, C16:1 n-7, C16:1 n-5, C17:1 n-9, C18:1 n-11, C18:1 n-9, C18:1 n-7, C20:1 $n-9$, and C24:1 n-9.

${ }^{9}$ PUFA is the sum of C18:2 n-6, C18:3 n-6, C18:3 n-3, C20:2 n-6, C18:2 c-9 t-11, C20:4 n-6, C20:3 n-3, C20:5 n-3, C22:5 n-3, and C22:6 n-3.

LM of bulls fed SC-based diets. Similarly, the percentage of the C20:5n-3 and C22:5n-3 FA were greater $(P$ $<0.01)$ in the LM of bulls fed SC-based diets. Therefore, it is likely that a ruminal escape occurred with SC-based diets. Bauman et al. (2003) showed that for most diets that the extent of C18:3n-3 biohydrogenation would be between 70 and $95 \%$. However, it has been shown that some of the FA in SC may be unaltered and may be deposited in the muscle tissue rather than being biohydrogenated in the rumen (Decker and Park, 2010).

The percentage of the FA C18:2 $c-9 t-11$ was greater $(P<0.01)$ in the LM of bulls fed SC60:40 and SCR than in bulls fed CS60:40 and CSR (Table 7). However, the percentage of this FA for SCR diet was similar $(P=0.15)$ to the percentage observed for those fed CS40:60 and SC40:60. The lowest $(P<0.01)$ values of CLA were observed in the LM of bulls fed the CS60:40 and CSR diets.

There was no difference in the abundance of SFA $(P=$ $0.66)$ or in the abundance of $n-9$ FA $(P=0.14)$ in the LM of bulls fed CS-based diets or SC-based diets at different ratios (Table 9). Dietary SFA may raise total and LDL cholesterol related to cardiovascular disease (Scollan et al., 2006) and various types of cancer (Scarborough et al., 2009). According to USDA, there is strong evidence that dietary SFA increase serum total and LDL cholesterol and that they are associated with an increased risk of cardio- vascular disease. Some studies show that a decrease in SFA equivalent to $5 \%$ of calories, replaced by PUFA or MUFA, decreases the risk of these diseases in adults.

The greatest $(P<0.01)$ abundance of MUFA was observed in bulls fed CS-based diets and SC40:60 (Table 9). However, the value observed for SC40:60 was similar to SC-based diets. Monounsaturated FA have been shown to positively influence human health. For example, C18:1 n-9 increases the level of high-density lipoprotein cholesterol and decreases the level of LDL cholesterol in human blood (Katan et al., 1994).

The abundance of PUFA was greater $(P<0.01)$ in the LM of bulls fed SC-based diets for all of the roughage ratios analyzed (Table 9). However, SC40:60 and CSR had similar $(P=0.54)$ levels of PUFA. Because PUFA is beneficial for human health, attempts have been made to increase PUFA abundance in beef. However, ruminal bacteria transform PUFA into MUFA or SFA during the process of ruminal biohydrogenation (Griinari et al., 2000). The finding that SC-based diets result in an increased abundance of PUFA indicates that a diet containing SC-based diet may be a viable alternative to modify the FA composition in beef muscle.

Although $n-6$ FA intake was greater to CS-based diets (Table 9), the abundance of the $n-6$ FA was greater 
$(P<0.05)$ in the LM of bulls fed SC-based diets and CSR than CS60:40 and CS40:60 (Table 9).

The abundance of $n-3$ FA was greater $(P<0.01)$ in the LM of bulls fed SC-based diet for all of the roughage ratios analyzed (Table 9). This finding indicates that SC-based diet can improve the FA composition of beef in terms of the $n-3$ FA abundance.

The lowest $(P<0.01) n-6: n-3$ ratio in LM of bulls was observed in cattle receiving the SC-based diets (Table 9). Her Majesty's Stationery Office (Department of Health, 1994) recommends that the $n-6: n-3$ ratio be less or equal to 4 . Values outside of this range are considered to be a risk factor for cancer, heart disease, and the formation of blood clots that can lead to heart attacks. All of the CSbased diets had n-6:n-3 ratios greater than 4 , whereas all of the SC-based diets had $n-6: n-3$ ratios less than 4 .

The PUFA:SFA ratio was greater $(P=0.04)$ in the LM of bulls fed SC-based diets than fed the CS60:40 and CS40:60 diets (Table 9). Her Majesty's Stationery Office (Department of Health, 1994) recommends that the PUFA:SFA ratio be greater than 0.45 . None of the diets we tested achieved this ratio. Recently, several studies have attempted to improve the PUFA:SFA ratio in cattle production systems in response to changes in the eating habits of consumers and the increasing demand for healthier food (McNeill et al., 2012). Researchers have focused on PUFA and the dietary balance between $n$-3 FA, formed from C18:3 n-3, and $n-6$ FA formed from C18:2 n-6 (Williams, 2000).

No differences $(P=0.54)$ were observed in the C12:0 FA content among the dietary treatments analyzed (Table 9).

The C18:2 $n-6$ content was greater $(P<0.01)$ for SC60:40 and SCR diets. Intermediate values $(P<0.01)$ were observed in the LM of bulls fed CS40:60 and SC40:60. The lowest values $(P<0.01)$ for C18:2 $n-6$ were observed in bulls fed the CS60:40 and CSR diets (Table 9).

The C18:3 $n$-3 FA content was greater $(P<0.01)$ in bulls fed SC-based diets for all of the roughage ratios analyzed (Table 9). However, C18:2 c-9 t-11 FA content was greater $(P<0.01)$ only in those animals that received a greater quantity of $\mathrm{SC}$ as roughage (i.e., the SC60:40 and SCR diets), which indicates that there is a relationship between $\mathrm{C} 18: 2 c-9 t-11$ and the amount of $\mathrm{SC}$ ingested. The $\mathrm{C} 20: 4 n-6$ FA content was greater $(P<$ $0.01)$ in the LM of bulls fed SC-based diets for all of the roughage ratios analyzed (Table 9 ).

The concentrations of $\mathrm{C} 20: 3 n-3$ and $\mathrm{C} 20: 5 n-3$ were greater $(P<0.01)$ in the LM of bulls fed the SC60:40 and SCR diets (Table 9). Therefore, bulls fed a greater SC roughage ratio, or those that received a greater roughage ratio for a certain period of time, exhibited a FA composition more beneficial to human health compared to bulls fed CS-based diets or those fed a lower $\mathrm{SC}$-based diet roughage ratio.

\section{Conclusions}

To maintain similar growth performance, CS60:40 and CSR diets may be replaced by SC40:60 (\% DM) in feedlot diets fed to crossbred Holstein $\times$ Zebu bulls. It is possible to obtain additional ADG in bulls fed reverse diets. Feeding the SC60:40 diet during the first $42 \mathrm{~d}$ and the SC40:60 diet during the last $42 \mathrm{~d}$ their feedlot time, animals show greater ADG in relation to the diet with a greater level of roughage during $84 \mathrm{~d}$. Longissimus muscle from bulls fed SC-based diets has a greater abundance of EFA, particularly those belonging to the $n-3$ class. Bulls fed SC-based diets also have a greater amount of CLA in LM compared to bulls fed CS-based diets.

\section{LITERATURE CITED}

American Association of Cereal Chemists. 2003. Approved methods of the American Association of Cereal Chemists. 10th ed. Amer. Assoc. Cereal Chem., St. Paul, MN.

AOAC. 2000. Official methods of analysis. 17th ed. AOAC Inc., Arlington, VA.

AOAC. 2006. Official methods of analysis. 18th ed. AOAC Inc., Gaithersburg, MD.

AOAC. 2012. Official methods of analysis. 19th ed. AOAC Inc., Arlington, VA.

Bauman, D. E., J. W. Perfield, and M. J. Veth. 2003. New perspectives on lipid digestion and metabolism in ruminants. In: Proc. Cornell Nutr. Conf., Ithaca, NY, p. 175-189. www.ansci.cornell. edu/bauman/cla/conference_proceedings/articles/2003_cnc_ bauman_et_al.pdf. (Accessed Dec. 21, 2013.)

Bligh, E. G., and W. J. Dyer. 1959. A rapid method of total lipid extraction and purification. Can. J. Biochem. Physiol. 37:911-917.

Buchanan, J. W., A. J. Garmyn, G. G. Hilton, D. L. VanOverbeke, Q. Duan, D. C. Beitz, and R. G. Mateescu. 2013. Comparison of gene expression and fatty acid profiles in concentrate and forage finished beef. J. Anim. Sci. 91:1-9.

Campbell, M. K. 1999. Biochemistry. 3rd ed. Harcourt Brace College Publishers, San Diego, CA.

Creek, M. J., and H. A. Squire. 1976. Use of a slaughter technique for technical and economic evaluation of sugar cane and maize silage based rations. Tropical Anim. Prod. 1:71-82.

Decker, E. A., and Y. Park. 2010. Healthier meat products as functional foods. Meat Sci. 86:49-55.

Delgado-Lista, J., P. Perez-Martinez, J. Lopez-Miranda, and F. PerezJimenez. 2012. Long chain omega-3 fatty acids and cardiovascular disease: A systematic review. Br. J. Nutr. 107:S201-S213.

Department of Health. 1994. Nutritional aspects of cardiovascular disease. In: 46th report on health and social subjects. HSMO, London, UK.

Detmann, E., and S. C. Valadares Filho. 2010. On the estimation of non-fibrous carbohydrates in feeds and diets. Arq. Bras. Med. Vet. Zootec. 62:980-984.

Fernandes, A. R. M., A. A. M. Sampaio, W. Henrique, D. Perecini, E. A. Oliveira, and R. R. Túllio. 2007. Economic evaluation and performance of feedlot male and female Canchim fed corn silage and concentrate or sugar cane plus concentrate with sunflower seed based diets. Rev. Bras. Zootec. 36:855-864.

Fernandes, A. R. M., A. A. M. Sampaio, W. Henrique, R. R. Tullio, E. A. Oliveira, and T. M. Silva. 2009. Chemical traits and fatty acids composition of beef from young bulls, steers and heifers fed corn silage and concentrate or sugarcane and concentrate with sunflower grains. Rev. Bras. Zootec. 38:705-712. 
Freitas, A. K., J. F. P. Lobato, L. L. Cardoso, J. U. Tarouco, R. M. Vieira, D. R. Dillenburg, and I. Castro. 2014. Nutritional composition of the meat of Hereford and Braford steers finished on pastures or in a feedlot in southern Brazil. Meat Sci. 96:353-360.

Griinari, J. M., B. A. Corl, and S. H. Lacy. 2000. Conjugated linoleic acid is synthesized endogenously in lactating dairy cows by delta 9 desaturase. J. Nutr. 130:2285-2291.

Hunter, J. E., J. Zhand, and P. M. Kris-Etherton. 2010. Cardiovascular disease risk of dietary stearic acid compared with trans, other saturated, and unsaturated fatty acids: A systematic review. Am. J. Clin. Nutr. 91:46-63.

International Organization for Standardization (ISO). 1978. Animal and vegetable fats and oils- preparation of methyl esters of fatty acids. ISO 5509. ISO, Geneva, Switzerland.

Katan, M. B., P. L. Zock, and R. P. Mensink. 1994. Effects of fats and fatty acid on blood lipids in humans: On review. Am. J. Clin. Nutr. 60:1017-1022.

Khattab, I. M., A. Z. M. Salem, A. M. Abdel-Wahed, and K. Z. Kewan. 2013. Effects of urea supplementation on nutrient digestibility, nitrogen utilization and rumen fermentation in sheep fed diets containing dates. Livest. Sci. 155:223-229.

Licitra, G., T. M. Hernandez, and P. J. Van Soest. 1996. Standardization of procedures for nitrogen fractionation of ruminant feeds. Anim. Feed Sci. Technol. 57:347-358.

Lippke, H., W. C. Ellis, and B. F. Jacobs. 1986. Recovery of indigestible fiber from feces of sheep and cattle on forage diets. J. Anim. Sci. 69:403-412.

Magalhães, A. L. R., J. M. S. Campos, L. S. Cabral, R. Mello, J. A. Freitas, R. A. Torres, S. C. Valadares Filho, and A. J. Assis. 2006. Effects of replacing corn silage with sugarcane on production and ruminal metabolism of lactating dairy cows. Rev. Bras. Zootec. 35:591-599.

McNeill, S. H., K. Harris, T. G. Field, and M. E. Van Elswyk. 2012. The evolution of lean beef: Identifying lean beef in today's U.S. marketplace. Meat Sci. 90:1-8.

Menezes, G. C. C., S. C. Valadares Filho, F. A. Magalhães, R. F. D. Valadares, L. D. Mariz, E. Detmann, O. G. Pereira, and M. I. Leão. 2011. Total and partial digestibility, rates of digestion obtained with rumen evacuation and microbial protein synthesis in bovines fed fresh or ensiled sugar cane and corn silage. Rev. Bras. Zootec. 40:1104-1113.

Mertens, D. R., M. Allen, J. Carmany, J. Clegg, A. Davidowicz, M. Drouches, K. Frank, D. Gambin, M. Garkie, B. Gildemeister, D. Jeffress, C. S. Jeon, D. Jones, D. Kaplan, G. N. Kim, S. Kobata, D. Main, X. Moua, B. Paul, J. Robertson, D. Tayson, N. Thiex, J. Williams, and M. Wolf. 2002. Gravimetric determination of amylase-treated neutral detergent fiber in feeds with refluxing in beakers or crucibles: Collaborative study. J. AOAC Int. 85:1217-1240.

National Forage Testing Association. 1993. Total dry matter by microwave drying to constant weight. In: Forage analyses procedures. www.foragetesting.org/lab_procedure/sectionB/2.1/ part2.1.3.htm. Accessed 11 Dec. 2012.

Oliveira, A. S., E. Detmann, J. M. S. Campos, D. S. Pina, S. M. Souza, and M. G. Costa. 2011. Meta-analysis of the impact of neutral detergent fiber on intake, digestibility and performance of lactating dairy cows. Rev. Bras. Zootec. 40:1587-1595.

Oliveira, E. A., A. A. M. Sampaio, W. Henrique, T. M. Pivaro, B. L. Rosa, A. R. M. Fernandes, and A. T. Andrade. 2012. Quality traits and lipid composition of meat from Nellore young bulls fed with different oils either protected or unprotected from rumen degradation. Meat Sci. 90:28-35.
Orskov, W. R., and F. D. D. Hovell. 1978. Digestión ruminal del heno (medido através de bolsas de dacron) en el ganado alimentado con caña de azúcar e heno de pangola. (In Spanish.) Trop. Anim. Health Prod. 3:9-11.

Pate, F. M., P. M. Fairhurst, and J. T. K. Munthali. 1985. Urea levels and supplemental energy sources in sugarcane diets. J. Anim. Sci. 61:252-259.

Pinto, A. P., J. J. S. Abrahão, J. A. Marques, W. G. Nascimento, D. Perotto, and S. M. B. Lugão. 2010. Performance and carcass characteristics of crossbred young bulls finished in a feedlot on diets with sorghum silage substituted by sugar cane. Rev. Bras. Zootec. 39:198-203.

Prado, I. N., R. H. Ito, J. M. Prado, I. M. Prado, P. P. Rotta, M. Matsushita, J. V. Visentainer, and R. R. Silva. 2008a. The influence of dietary soyabean and linseed on the chemical composition and fatty acid profile of the longissimus dorsi muscle of feedlot-finished bulls. J. Anim. Feed Sci. 17:307-317.

Prado, I. N., R. M. Prado, P. P. Rotta, J. V. Visentainer, J. L. Moletta, and D. Perotto. 2008b. Carcass characteristics and chemical composition of the longissimus dorsi muscle of crossbred bulls (Bos taurus indicus vs Bos taurus taurus) finished in feedlot. J. Anim. Feed Sci. 17:295-306.

Prates, L. L., R. F. D. Valadares, S. C. Valadares, E. Filho, S. A. Detmann, J. M. S. Santos, S. G. Braga, I. Pellizzon, and K. S. Barbosa. 2012. Endogenous fraction and urinary recovery of purine derivates in Nellore and Holstein heifers with abomasal purine infusion. Livest. Sci. 150:179-186.

Ribeiro, S. S., J. T. Vasconcelos, M. G. Morais, C. B. C. F. Ítavo, and G. L. Franco. 2011. Effects of ruminal infusion of slow-release polymer-coated urea or conventional urea on apparent nutrient digestibility, in situ degradability, and rumen parameters in cattle fed low-quality hay. Anim. Feed Sci. Technol. 164:53-61.

Rotta, P. P., R. M. Prado, I. N. Prado, M. V. Valero, J. V. Visentainer, and R. R. Silva. 2009. The effects of genetic groups, nutrition, finishing system and gender of Brazilian cattle on carcass characteristics and beef composition and appearance: A review. Asian-Australas. J. Anim. Sci. 22:1718-1734.

Rotta, P. P., S. C. Valadares Filho, E. Detmann, L. F. Costa e Silva, F. A. C. Villadiego, E. M. G. Burgos, and F. A. S. Silva. 2013. Nutrient requirements of energy and protein for Holstein $\times$ Zebu bulls finished in feedlot. Semina 34:1859-1866.

Scarborough, P., S. Allender, M. Rayner, and M. Goldacre. 2009. Validation of model-based estimates (synthetic estimates) of the prevalence of risk factors for coronary heart disease for wards in England. Health Place 15:596-605.

Scollan, N., J. F. Hocquette, K. Nuernberg, D. Dannenberger, I. Richardson, and A. Moloney. 2006. Innovations in beef production systems that enhance the nutritional and health value of beef lipids and their relationship with meat quality. Meat Sci. 74:17-33.

Segers, J. R., A. M. Stelzleni, T. D. Pringle, M. A. Froetschel, C. L. Ross, and R. L. Stewart Jr. 2013. Use of corn gluten feed and dried distillers grains plus soluble as a replacement for soybean meal and corn for supplementation in a corn silage-based stocker system. J. Anim. Sci. 91:950-956.

Simopoulos, A. P. 1999. Essential fatty acids in health and chronic disease. Am. J. Clin. Nutr. 70:560-569.

Smith, W. L. 2008. Nutritionally essential fatty acids and biologically indispensable cyclooxygenases. Trends Biochem. Sci. 33:27-37.

Souza, N. E., and J. V. Visentainer. 2006. Colesterol da mesa ao corpo. 1st ed. (In Portuguese.) Varela, Maringá, PR, Brazil.

Thomas, T. A. 1977. An automated procedure for the determination of soluble carbohydrates in herbage. J. Sci. Food Agric. 28:639-642. 
Valente, T. N. P., E. Detmann, S. C. Valadares Filho, M. Cunha, A. C. Queiróz, and C. B. Sampaio. 2011. In situ estimation of indigestible compounds contents in cattle feed and feces using bags made from different textiles. Rev. Bras. Zootec. 40:666-675.

Valero, M. V., F. Zawadzki, M. C. Françoso, M. S. Farias, P. P. Rotta, I. N. Prado, J. V. Visentainer, and L. M. Zeoula. 2011. Sodium monensin or propolis extract in the diet of crossbred (1/2 Red Angus vs. Nellore) bulls finished in feedlot: Chemical composition and fatty acid profile of longissimus muscle. Semina 32:1617-1626.

Van Soest, P. J., J. B. Robertson, and B. A. Lewis. 1991. Methods for dietary fiber neutral detergent fiber, and nonstarch polysaccharides in relation to animal nutrition. J. Dairy Sci. 74:3583-3597.

Van Wezemael, L., O. Ueland, R. Rodbotten, S. Smet, J. Scholderer, and W. Verbeke. 2012. The effect of technology information on consumer expectations and liking of beef. Meat Sci. 90:444-450.
Wilcox, E. B., M. B. Merkley, L. S. Galloway, D. A. Greenwood, W. Binns, J. A. Bennett, and L. E. Harris. 1953. The effect of feeding sucrose to beef cattle and swine on the dressing percentage and quality of meat. J. Anim. Sci. 12:24-32.

Williams, C. M. 2000. Dietary fatty acids and human health. Ann. Zootech. 49:165-180.

Woollett, A. L., K. D. Spady, and M. J. Dietschy. 1992. Saturated and unsaturated fatty acids independently regulate low-density lipoprotein receptor activity and production rate. J. Lipid Res. 33:77-88.

Xin, H. S., D. M. Schaefer, Q. P. Liu, D. E. Axe, and Q. X. Meng. 2010. Effects of polyurethane coated urea supplement on in vitro ruminal fermentation, ammonia release dynamics and lactating performance of Holstein Dairy cows fed a steam-flaked corn-based diet. Asian-Australas. J. Anim. Sci. 23:491-500. 